\title{
NATIONAL WATER-QUALITY ASSESSMENT PROGRAM Yellowstone River Basin
}

\section{AJ OR W ATER-QUALITY ISSUES IN THE YELLOWSTONE RIVER BASIN}

Assessing the water quality in the Yellowstone River Basin is important for the protection and utilization of the water resources. Changes in water quality can affect the entire ecosystem, raising concerns about drinking-water quality, habitat degradation or destruction, and loss of use of the resource. The Yellowstone River Basin NAWQA study will increase the scientific understanding of surface- and ground-water quality and the factors that influence water quality. This information will benefit the waterresource managers that need, but often lack, the data to implement effective management actions and evaluate long-term changes in water quality.

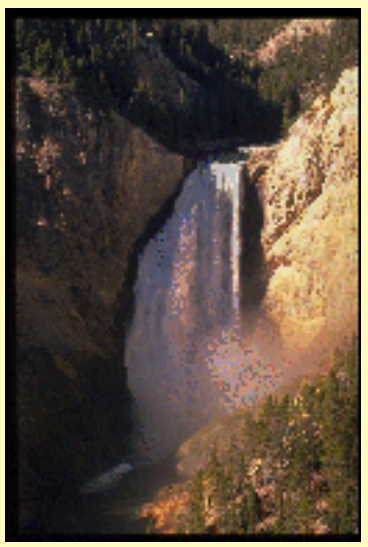

The Yellowstone River originates at the Continental Divide in Yellowstone National Park, Wyoming (photo of Lower Falls, Yellowstone National Park, courtesy of Wyoming Division of Tourism)

Major water-quality issues in the Yellowstone River Basin vary from potential degradation of pristine streams in headwater areas to industrial and agricultural effects in downstream reaches. The issues generally are related to effects of land and water use, but some are related to natural factors.

- Trace elements - Leachate from mine spoils and tailings can increase trace elements in both ground water and streams. Leaching of soils derived from marine shales of Cretaceous age in some locations has caused high concentrations of selenium in water resources. Geothermal areas, like those in the Yellowstone National Park area, can be sources of trace elements such as arsenic in both ground water and streams. Because of the widespread distribution of uranium-bearing rocks, elevated concentrations of radon and other radionuclides in water are a concern. Trace

\section{W HAT IS THE NAW QA PROGRAM?}

During the past 25 years, government and industry have made large financial investments aimed at improving water quality across the Nation. Major progress has been made; however, many water-quality issues remain. To address the need for consistent and scientifically sound information for managing the Nation's water resources, the U.S. Geological Survey began a full-scale National Water-Quality Assessment (NAWQA) Program in 1991. The overall goals of the NAWQA Program are to (1) describe current water-quality conditions for a large part of the Nation's freshwater streams and aquifers, (2) describe how water quality is changing over time, and (3) improve our understanding of the primary natural and human factors affecting water quality.

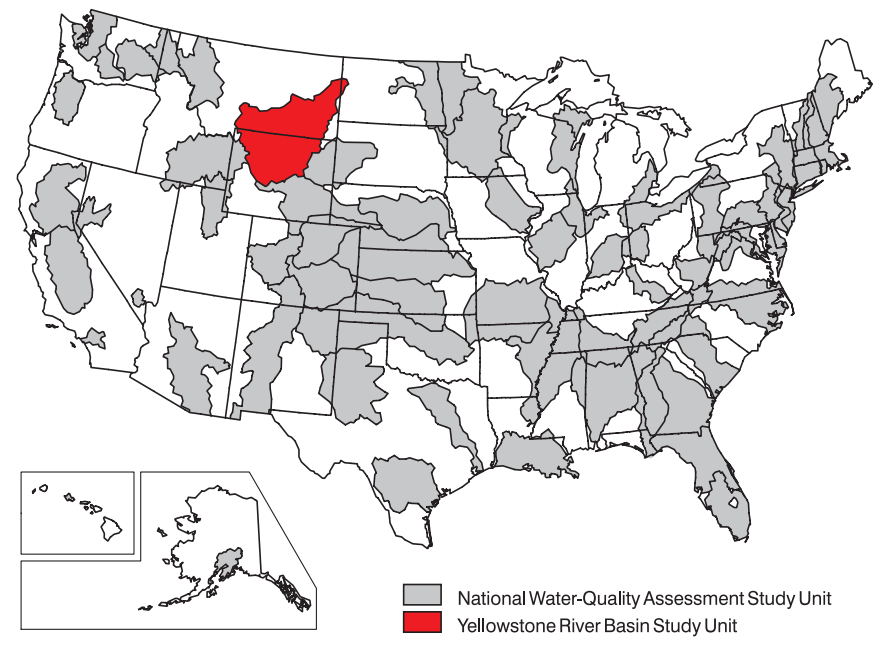

Figure 1. Map showing Yellowstone River Basin NAWQA study unit.

Assessing the quality of water in every location of the Nation would not be practical; therefore, NAWQA Program studies are planned within a set of areas called study units (fig. 1). These study units are composed of over 50 important river and aquifer systems that represent the diverse geography, water resources, and land and water uses of the Nation. The Yellowstone River Basin is one such study unit, designed to include the entire 70,100square-mile Yellowstone River drainage. Study activities by the U.S. Geological Survey in the Yellowstone River Basin began in 1997.

elements also can be associated with suspended sediments in streams.

Toxic compounds - Potential sources for toxic compounds in both ground water and streams include: leachate from abandoned and active landfills; pesticides and fertilizers from lawns and croplands; hydrocarbons from leaking tanks, refining operations, pipelines, and spills; and waste from industrial and commercial activities.

Salinity - Increases in the salinity of both ground water and streams can occur from saline ground water disposal, irrigation return flows, and some irrigation practices.
- Sedimentation - Loss of streambank vegetation, easily erodible soils, and many land-use activities can contribute to sediment problems in streams throughout the basin.

Other related issues - Other potential issues related to water quality in the basin include: acidification of water resources by leaching of mine spoils, nutrient enrichment of ground water and streams from fertilizers and animal and human waste, localized de-watering of sole-source aquifers, ground-water and stream quality related to coalbed methane production, and water-quality concerns on tribal lands. 


\section{STUDY UNIT DESCRIPTION}

The Yellowstone River basin study unit extends from central Wyoming north to include most of southeastern Montana and a small part of western North Dakota. The entire Yellowstone River watershed defines the study unit boundaries and includes all of the Wind/Bighorn, Powder, Tongue, and Clarks Fork Yellowstone tributary watersheds. Total area for the study unit is about 70,100 square miles (sq mi) of which 51 percent is in Montana, 48 percent is in Wyoming, and 1 percent is in North Dakota. Total population of the study unit was about 323,000 (1990 census), of which 206,000 were in Montana, 116,000 were in Wyoming, and 1,000 were in North Dakota.

The study unit lies within the Rocky Mountain System and Interior Plains physiographic divisions. Topography of the study unit in the Rocky Mountain System division varies from mountain ranges and high plateaus, including the Wind River Range, Bighorn Mountains, and Absaroka Plateau, to intermontane basins, such as the Wind River and Bighorn Basins. The highest elevations in the study unit are in the Wind River Range, where several peaks exceed 13,000 feet above sea level. The Interior Plains division part of the study unit varies from gently rolling plains to sharply dissected badlands. The lowest point in the study unit, 1,850 feet above sea level, is located at the mouth of the Yellowstone River in North Dakota.

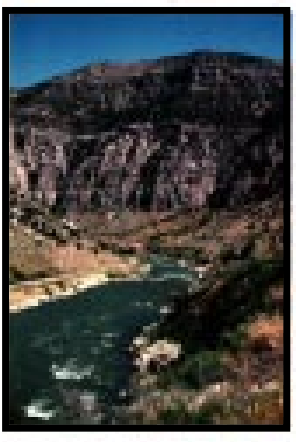

The Wind River flows north through the Wind River Canyon into the Bighorn Basin, where it becomes the Bighorn River at the Wedding of the Waters (photo courtesy of Wyoming Division of Tourism)

Climate in the study unit ranges from cold and moist in the mountainous areas to temperate and semiarid in the plains areas. Annual temperature extremes range from about 30 degrees Fahrenheit $\left({ }^{\circ} \mathrm{F}\right)$ below zero during the winter to hotter than $100^{\circ} \mathrm{F}$ during the summer. Mean annual temperatures range from $32^{\circ} \mathrm{F}$ at Cooke City, Montana to $48^{\circ} \mathrm{F}$ at Billings, Montana. Mean annual precipitation ranges from more than 60 inches in the mountains near Yellowstone National Park to less than 6 inches in the
Clarks Fork Yellowstone River valley. Mean annual snowfall ranges from more than 130 inches in Yellowstone National Park to about 16 inches in northeast Montana.

Rangeland is the dominant land use and land cover, with about 43 percent of the study unit composed of subhumid grassland and semiarid grazing land. The remaining land uses and land cover include grazed and ungrazed forest (19\%), grazed desert shrubland (16\%), mostly cropland and grazed cropland (non-irrigated: $11 \%$; irrigated: $5 \%$ ), grazed open woodland (5\%), and alpine and lakes (1\%).

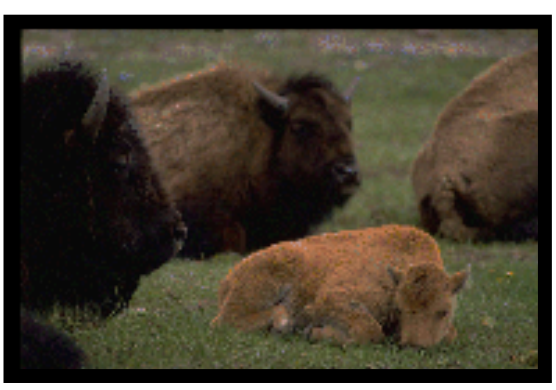

Grazing by domestic livestock and other species on range and grasslands is a major land use in the study unit (photo of North American Bison courtesy of Wyoming Division of Tourism)

Major land-use industries in the study unit include coal and metals mining, oil and gas production, and agriculture. About 30 active mines remove low-sulfur coal by surface strip-mining methods from the large coal reserves in the Tongue and Powder River Basins. Most of the metals mining occurs in the mountainous regions of the study unit. Oil and gas is produced from reservoirs in the Powder River and Big Horn Basins. Much of the agricultural industry in the study unit is related to livestock production. The agricultural industry also includes farming of irrigated cropland along alluvial valleys and benches.

Drainage areas for the major tributary watersheds range from $22,414 \mathrm{sq}$ mi for the Wind/Bighorn River to about 2,032 sq mi for the Clarks Fork Yellowstone River. Mean annual flow ranges from 12,750 cubic feet per second $\left(\mathrm{ft}^{3} / \mathrm{sec}\right)$ for the Yellowstone River at Sidney Montana, to about $421 \mathrm{ft}^{3} /$ $\mathrm{sec}$ for the Tongue River near the mouth. Streamflow in all the major watersheds is affected by diversions. While there are no reservoirs on the mainstem Yellowstone River, several reservoirs regulate flow in the Wind/Bighorn and Tongue River watersheds.

Alluvial deposits of Quaternary age along major tributaries and the mainstem Yellowtone River are the primary sources of ground water in the study unit upstream of Billings, Montana. Downstream from Billings, in
Drainage area and mean annual streamflow for major tributary watersheds, Yellowstone River

[Streamflow data through water year 1996; Note: mean annual streamflow is from streamflow-gaging station near mouth of respective river.]

\begin{tabular}{|c|c|c|c|}
\hline \multirow[b]{2}{*}{ River } & \multicolumn{2}{|c|}{ Drainage area } & \multirow{2}{*}{$\begin{array}{c}\text { Mean annual } \\
\text { streamflow } \\
\text { in cubic feet } \\
\text { per second }\end{array}$} \\
\hline & $\begin{array}{l}\text { Square } \\
\text { miles }\end{array}$ & $\begin{array}{c}\text { Percent } \\
\text { of study } \\
\text { unit }\end{array}$ & \\
\hline $\begin{array}{l}\text { Clarks Fork } \\
\text { Yellowstone River }\end{array}$ & 2,032 & 3 & 1,032 \\
\hline Wind/Bighorn River & 22,414 & 32 & 3,810 \\
\hline Tongue River & 5,397 & 8 & 421 \\
\hline Powder River & 13,189 & 19 & 586 \\
\hline Yellowstone River ${ }^{1}$ & 69,103 & 99 & 12,750 \\
\hline
\end{tabular}

addition to alluvial sources of ground water, sandstone and coal beds within the Fort Union Formation of Tertiary age and sandstones in the Fox Hills Formation of Upper Cretaceous age are important bedrock aquifers. The Wind River Formation of Tertiary age is used to supply irrigation water in the Riverton, Wyoming area with some wells yielding as much as 3,000 gallons per minute. Other aquifers in Mesozoic and Paleozoic units are productive but have not been extensively developed.

About 98 percent of the total water used in the study unit in 1990 was surface water. Most of this water—about 99 percent—was used by the agricultural industry for crops and livestock. However, ground water is an important resource in the study unit. About 97 percent of the domestic water supply and about 27 percent of the public water supply is from ground water. About 62 percent of the total ground-water use in 1990 was for agricultural purposes. Public supply, mining, power generation, and industry made up most of the remaining uses of surface- and ground-water in the study unit.

Reported surface and ground water used by category in the Yellowstone River Basin, 1990

[Note: category and total amounts expressed to two significant figures.]

\begin{tabular}{lcc}
\hline \multicolumn{1}{c}{ Category } & $\begin{array}{c}\text { Water used in millions of } \\
\text { gallons per day }\end{array}$ \\
\cline { 2 - 3 } Surface water Ground water
\end{tabular}

${ }^{1}$ Source: U.S. Geological Survey digital data, 1990. 


\section{SCHEDULE OF STUDY UNIT ACTIVITIES}

The Yellowstone River Basin study is one of a set of NAWQA studies started in 1997. Planning, study design, and analysis of existing data will occur during the first two years of the study (fig. 2). After the 2-year planning period, ground-water, surface-water, and biological data will be collected intensively for 3 years, a period referred to as the high-intensity phase. A lowintensity phase follows for 6 years, during which water quality will be monitored at selected sites and areas assessed during the high-intensity phase. This cycle (without the planning period) will be repeated starting in 2007. This combination of high- and low-intensity monitoring phases allows the NAWQA Program to examine trends in water quality over time.

During the planning period, existing data and results from previous studies will be reviewed to help understand the primary physical, chemical, and biological factors that affect water quality in the study unit and to identify gaps in the current data. Descriptions of how land use and land cover, soil,

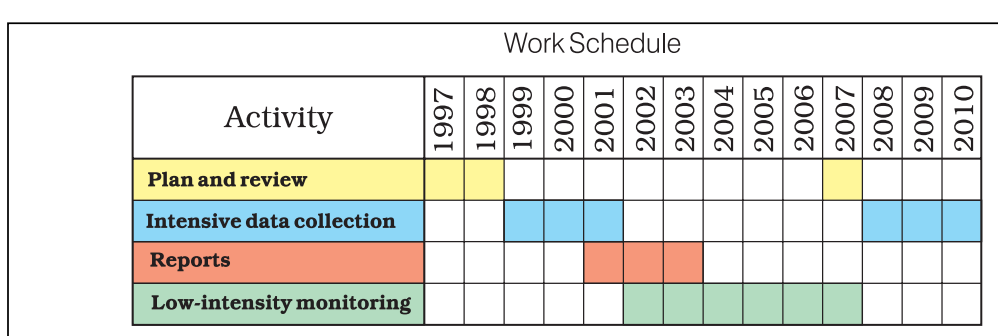

Figure 2. Timeline of study unit activities.

geology, physiography, climate, and drainage characteristics may influence water quality are to be included in technical and non-technical reports. The existing information, along with field checks of existing monitoring stations and possible sampling sites, and field reconnaissance data, will be used to design a sampling program for the study unit.

During the high-intensity phase, new waterquality and biological data will be collected from selected areas at both local and regional scales to describe water-quality conditions across the study

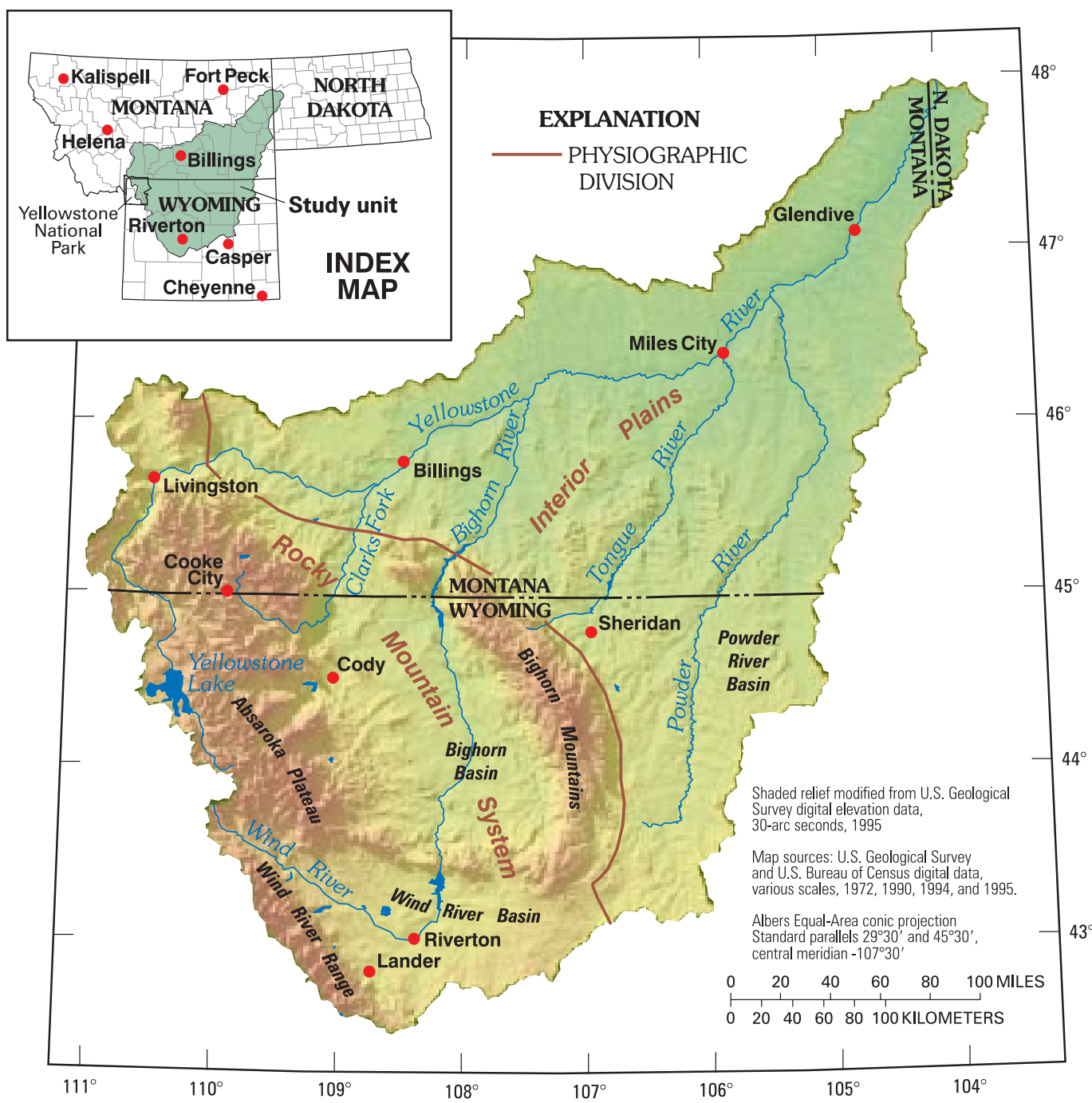

Figure 3. Topography, generalized physiography and hydrography, and selected towns and geographic features, Yellowstone River Basin. 


\section{ASSESSING WATER QUALITY IN THE YELLOW STONE RIVER BASIN STUDY UNIT}

All NAWQA studies have several common components designed to assess water quality across the Nation. Consistent data-collection and assessment methods make this possible and are critical for providing uniform and comparable information on water quality for the Nation. Surface-water, ground-water, and ecological studies will be done at local (a few square miles to hundreds of square miles) and regional (thousands of square miles) scales to understand the water-quality conditions and issues in a study unit. The data from all the NAWQA studies are aggregated to provide national water-quality assessments. Partnerships and cooperative studies between local, State, and Federal agencies can be developed to help meet specific needs. The following discussions describe the surfacewater, ground-water, and ecological monitoring components of the Yellowstone River Basin NAWQA study. The basic design described in the following sections is similar among NAWQA study units nationwide.

\section{Surface Water}

Surface water is monitored at stream sites. These sites are classified as basic-fixed sites or intensive-fixed sites, according to the frequency of the sampling and the types of data collected. These sites are used to monitor water-quality characteristics such as basic field parameters and concentrations of major ions, nutrients, pesticides, and possibly volatile organic compounds (VOCs) and trace elements. These sites are selected to determine water-quality conditions in relation to important environmental settings in the study unit. Most NAWQA study units have about eight basicfixed and four intensive-fixed sites. Basic-fixed sites are sampled on a regular basis, typically monthly, for the duration of the 3-year highintensity phase. The intensive-fixed sites are monitored frequently, typically weekly during key time periods, at least for 1 year, to characterize short-term variations of water quality.

Basic-fixed or intensive-fixed sites can be classified as either indicator or integrator sites. Indicator sites represent relatively homogeneous and usually small basins associated with environmental settings, such as a specific land use that is considered to be important for understanding water-quality in the study unit. Integrator sites are established at downstream points in large drainage basins, which are relatively heterogeneous, and incorporate complex combinations of land-use settings. These sites represent many of the land uses in the basin.
Other types of samples also are collected from surface water. Synoptic sampling is done as short-term investigations of specific waterquality conditions during selected hydrologic periods, such as low streamflow, to provide greater spatial data coverage and to allow investigators to assess basic-fixed or intensivefixed sites are representative of streams throughout the study unit.

\section{Ground Water}

Ground-water studies of a typical NAWQA study are composed of three components: (1) sub-unit survey, (2) land-use studies, and (3) an optional flow-path study. The sub-unit survey is intended to characterize water quality in the major aquifers of the study unit and does not target specific land uses. Several wells are randomly selected to be sampled in aquifer subunits throughout the study unit.

The land-use survey attempts to characterize ground-water quality associated with recentlyrecharged water in particular land uses. Landuse studies emphasize the study of shallow aquifer systems so that the influences of both land-use practices and natural conditions can be assessed. Several wells are randomly selected within each land use for each aquifer type. Ground-water samples are analyzed for major ions, nutrients, pesticides, VOCs, and trace elements. Results from the land-use study can be used to compare with results from the sub-unit survey to determine the effect of land use on ground-water quality.

The flow-path study is intended to answer important questions about processes controlling shallow ground-water movement and quality. The flow-path study is designed to trace the chemical changes that occur to water as it enters the ground-water flow system, travels along a flow path, and eventually discharges. Water samples collected from several existing or newly installed wells are analyzed for representative constituents.

\section{Ecology}

Ecological studies are conducted along with the surface-water and ground-water sampling activities. Aquatic biological communities are surveyed at the basic and intensive fixed sites during the three years of the high-intensity sampling phase. These investigations are conducted along a delineated stream reach and include an aquatic and riparian habitat assessment of the site and annual surveys of the fish, algal, and benthic invertebrate communities. This approach is intended to provide insight into ecological variability over time, the role that water quality plays in community structure and stability, and differences with respect to various environmental settings. Additionally, studies are conducted to provide overviews of the ecological status of the study unit. Trace elements and synthetic organic compounds are analyzed in bed sediment and fish tissue at selected sites to determine their occurrence and distribution in the study unit. Ecological synoptic studies are conducted within a network of sites to evaluate spatial variability of biological communities or to address issues of special concern within the study unit.

\section{COMMUNICATION AND COORDINATION}

Communication and coordination between the U.S. Geological Survey and other scientific and land- and watermanagement organizations are critical components of the NAWQA Program. Each study-unit investigation maintains a liaison committee consisting of representatives from Federal, State, and local agencies, universities, the private sector, watershed organizations, and those who have waterresource responsibilities and interests. Activities include the exchange of information about regional and local waterquality issues, identification of sources of data and information, assistance in the design and scope of study products, and the review of study planning documents and reports. The Yellowstone River Basin liaison committee will be formed in 1997.

The overall success of the Yellowstone River Basin NAWQA study will depend on the advice, cooperation, and information from the public and many Federal, State, regional, and local agencies concerned about the basin's water resources. The assistance and suggestions of all are welcome.

\section{FOR M ORE INFORM ATION}

Information on technical reports and hydrologic data related to the NAWQA Program can be obtained from:

Tom Quinn, NAWQA Chief

U.S. Geological Survey

Water Resources Division

2617 East Lincolnway, Suite B

Cheyenne, Wyoming 82001-5662

(307) 778-2931

E-mail:nawqamail@mailcheyenne.cr.usgs.gov Internet:

http://wyoming.usgs.gov/YELL/yell.html

By: Kirk Miller and Tom Quinn

Layout by: Sue Roberts and Kirk Miller; modified from Glo Morrill and Jim Caras

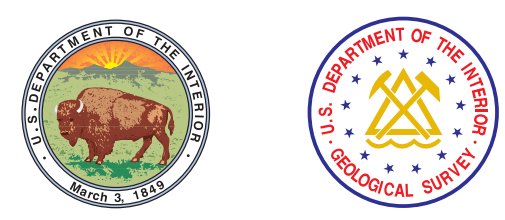

